DUN-185-1

Cover Sheet for a Hanford Historical Document Released for Public Availability

Released 1994

Prepared for the U.S. Department of Energy under Contract DE-AC06-76RLO 1830

Pacific Northwest Laboratory Operated for the U.S. Department of Energy by Battelle Memorial Institute 


\section{DISCLAIMER}

This report was prepared as an account of work sponsored by an agency of the United States Government. Neither the United States Government nor any agency thereof, nor any of their employees, make any warranty, express or implied, or assumes any legal liability or responsibility for the accuracy, completeness, or usefulness of any information, apparatus, product, or process disclosed, or represents that its use would not infringe privately owned rights. Reference herein to any specific commercial product, process, or service by trade name, trademark, manufacturer, or otherwise does not necessarily constitute or imply its endorsement, recommendation, or favoring by the United States Government or any agency thereof. The views and opinions of authors expressed herein do not necessarily state or reflect those of the United States Government or any agency thereof. 


\section{DISCLAIMER}

Portions of this document may be illegible in electronic image products. Images are produced from the best available original document. 


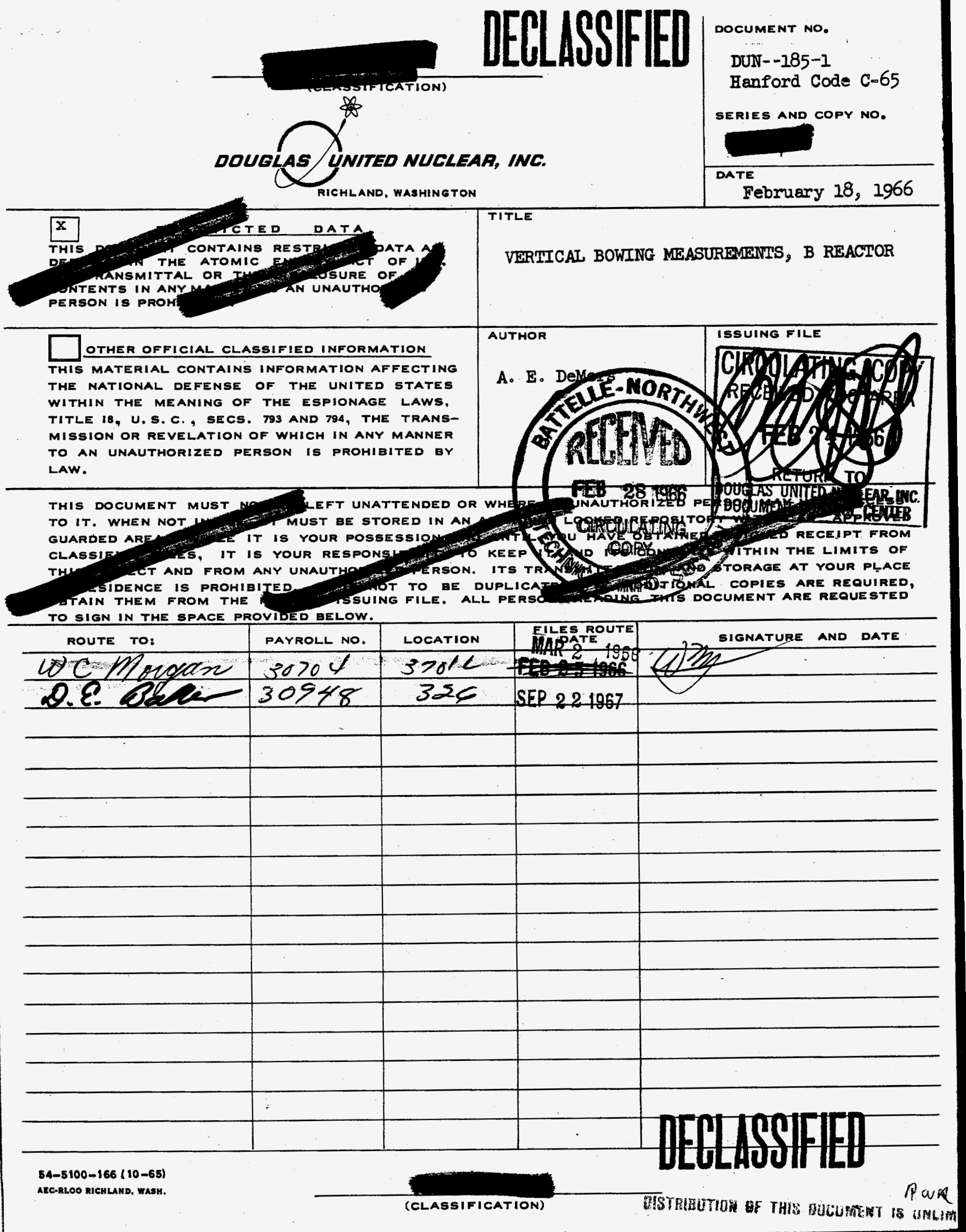


DISTRIBUTION

Douglas United Nuclear, Inc.

1. WN AdachI

2. JW Baker

3. JH Ferguson

4. G. Fiorelli

5. A Russell

6. GL Smith

7. DUN Files

8. DUN Records

This Document Classified By:

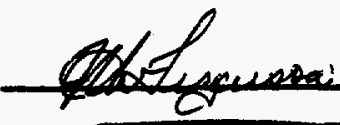

\section{Battelle-Northwest}

9. WC Morgan
Clessification Cancolled and Changed To

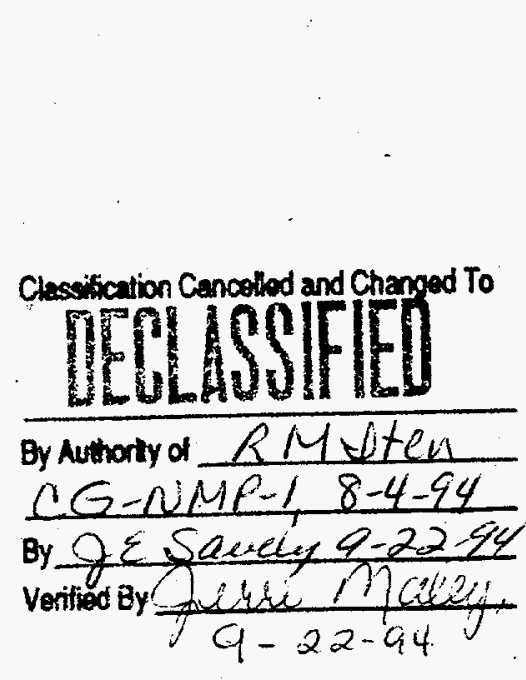

\title{
VERTICAL BOWING MEASUREMENTS, B REACTOR
}

\author{
A. E. DeMers
}

DOUGLAS UNITED NÜCLEAR, INC.

RICHLAND. WASHINGTON

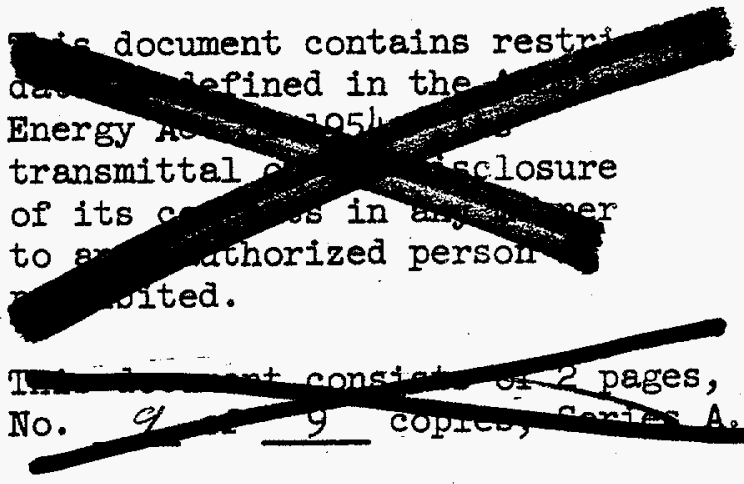

\section{NOTICE}

THIS REPORT WAS PREPARED FOR USE WITHIN DOUGLAS UNITED NUCLEAR, INC. IN THE COURSE OF WORK UNDER ATOMIC ENERGY COMMISSION CONTRACT AT(45-1) - 1857, AND ANY VIEWS OR OPINIONS EXPRESSED IN THE REPORT ARE THOSE OF THE AUTHOR ONLY. THIS REPORT IS SUBJECT TO REVISION UPON COLLECTION OF ADDITIONAL DATA.

\section{LEGAL NOTICE}

THIS REPORT WAS PREPARED AS AN ACCOUNT OF GOVERNMENTISGSNSOREU WORK. NEITHER THE UNITED STATES, NOR THE COMMISSION, NOR ANY PERSON ACTING ON BEHALF OF THE COMMISSION:

A. MAKES ANY WARRANTY OR REPRESENTATION, EXPRESSED OR IMPLIED, WITH RESPECT TO THE ACCURACY, COMPLETENESS; OR USEFULNESS OF THE INFORMATION CONTAINED IN THIS REPORT, OR THAT THE USE OF ANY INFORMATION, APPARATUS, METHOD, OR PROCESS DISCLOSED IN THIS REPORT MAY NOT INFRINGE PRIVATELY OWNED RIGHTS; OR

B. ASSUMES ANY LIABILITIES WITH RESPECT TO THE USE OF, OR FOR DAMAgEs RESULTING FROM THE USE OF ANY INFORMATION, APPARATUS, METHOD, OR PROCESS DISCLOSED IN THIS REPORT.

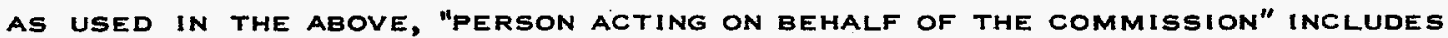
ANY EMPLOYEE OR CONTRACTOR OF THE COMMISSION, OR EMPLOYEE OF SUCH CONTRACTOR, TO THE EXTENT THAT SUCH EMPLOYEE OR CONTRACTOR OF THE COMMISSION, OR EMPLOYEE OF SUCH CONTRACTOR PREPARES, DISSEMINATES, OR PROVIDES ACCESS TO, ANY INFORMATION PURSUANT TO HIS EMPLOYMENT OR CONTRACT WITH THE COMMISSION, OR HIS EMPLOYMENT WITH SUCH CONTRACTOR. 


\section{VERTICAI BOWING MEASUREMENTS - B REACTOR}

Distance from

Inlet Flange

$18^{\prime \prime}$
$2^{\prime}$
$3^{\prime}$
$4^{\prime}$
$5^{\prime}$
$6^{\prime}$
$7^{\prime}$
$8^{\prime}$

$8^{\prime \prime} 4^{\prime \prime}$

8 '8"

$8^{\prime} 10^{\prime \prime}$

$9^{\prime}$

$9^{\prime} 2^{\prime \prime}$

9'4"

$9^{\prime} 6^{\prime \prime}$

$9^{\prime} 8^{\prime \prime}$

$9^{\prime} 10^{\prime \prime}$

$10^{\prime}$

$10^{\prime \prime} 4^{\prime \prime}$

11 '

$12^{\prime}$

$13^{\prime}$

$14^{\prime}$

$15^{\prime}$

$16^{\prime}$

\author{
$\triangle$ Height \\ Tube 4574
}

$$
\begin{array}{r}
.00 \\
+\quad .00 \\
+.00 \\
+\quad .10 \\
+\quad .04 \\
+\quad .79 \\
+1.37 \\
+1.76 \\
+1.86 \\
+2.00 \\
+1.98
\end{array}
$$$$
+1.56
$$$$
+1.36
$$$$
+.94
$$$$
+.27
$$$$
-.42
$$$$
-.07
$$$$
-.63
$$$$
-1.91
$$

\section{Distance from \\ Inlet Flange}

$17^{\prime}$

$18^{\prime}$

$19^{\circ}$

$20^{\prime}$

$21^{\prime}$

$22^{\prime}$

$23^{\prime}$

$24^{\prime}$

$25^{\prime}$

$26^{\prime}$

$27^{\prime}$

28 '

$29^{\prime}$

$30^{\prime}$

$3 I^{\prime}$

$32^{\prime}$

$33^{\prime}$

34 ,

$35^{\prime}$

$36^{\prime}$
Height Tube 4574

$-2.06$

$-2.21$

$-2.35$

$-2.33$

$-2.33$

$-2.25$

$-2.10$

$-1.86$

$-1.60$

- 1.29

- .90

- .40

$+.04$

$+.44$

$+.75$

$+.92$

$+.85$

$+.76$

$+.64$

$+.51$

These data were taken on 2-10-66 by B. K. Markfelder and D. I. Frank.

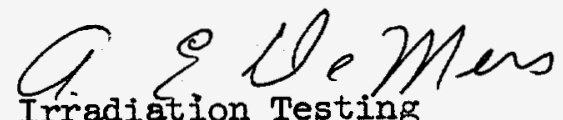

AE -DeMers : DPC :msp 